\title{
RELATIONSHIP BETWEEN JOB \\ PERFORMANCE, WELL-BEING, JUSTICE, AND ORGANIZATIONAL SUPPORT: A MULTILEVEL PERSPECTIVE
}

\author{
NATASHA FOGAÇA ${ }^{1}$ \\ (iD) https://orcid.org/0000-0002-6536-7546 \\ FRANCISCO A. COELHO JUNIOR ${ }^{1}$ \\ (iD https://orcid.org/0000-0002-1820-5448 \\ TATIANE PASCHOAL ${ }^{1}$ \\ (iD) https://orcid.org/0000-0002-2688-1411 \\ MARIO C. FERREIRA ${ }^{1}$ \\ (D) https://orcid.org/0000-0002-4962-5154 \\ CAMILA C. TORRES ${ }^{2}$ \\ (D) https://orcid.org/0000-0002-3604-9119
}

To cite this paper: Fogaça, N., Coelho, F. A., Junior, Paschoal, T., Ferreira, M. C., \& Torres, C. C. (2021). Relationship between job performance, well-being, justice, and organizational support: A multilevel perspective. Revista de Administração Mackenzie, 22(4), 1-27. doi:10.1590/1678-6971/ eRAMG210108

Submission: June 3, 2019. Acceptance: Nov. 17. 2020.

\footnotetext{
1 University of Brasília (UnB), Brasília, DF, Brazil.

2 Iesb University Center, Brasília, DF, Brazil.
} 


\section{ABSTRACT}

Purpose: This research was based on the "happy, productive worker" hypothesis. The objective was to analyze the predictive relationships, through a multilevel approach, between the variables well-being at work, organizational justice, organizational support, and the dependent variable individual job performance.

Originality/value: The multilevel study of individual job performance and its relations with well-being and organizational variables are still a current gap in the literature, as well as the possibility of testing whether well-being at work can be considered a collective phenomenon. The presence of organizational support in the model, operationalized at the team level, represents an important contribution to the development of theories focused on teams' roles in organizations, especially their impact on organizational variables.

Design/methodology/approach: Considering the proposed analysis at two different levels, a multilevel design model was adopted. The final sample consisted of 730 individuals and 32 units. The data were collected through a questionnaire composed of four previously validated scales. Data analysis followed the six steps proposed by Hox, Moerbeek, and Schoot (2017) for multilevel models for each of the samples.

Findings: The explanatory model presented a predictive relationship between achievement (well-being at work factor), operationalized as an individual-level variable, and individual job performance; a predictive relationship between interactional justice, also operationalized as an individual-level variable, and individual job performance, and a predictive relationship between collective perceptions of organizational support, operationalized as a team-level variable, and individual job performance.

\section{KEYWORDS}

Collective perceptions. Individual job performance. Well-being at work. Organizational justice. Organizational support. 


\section{INTRODUCTION}

The "happy, productive worker" hypothesis has been extensively studied, and the search for possible relationships between these phenomena is seen as the "Holy Grail" of organizational behavior research. Although it is an old issue, the relationship between job performance and happiness still represent a gap in the literature and remain relevant and challenging in human resources management (Guerci, Hauff, \& Gilardi, 2019; Hauff, Guerci, \& Gilardi, 2020; Warr \& Nielsen, 2018). Job satisfaction is one of the most commonly used variables to discuss this relationship. Despite their emotional appeal, job satisfaction measures often do not address emotions and moods, only asking individuals to evaluate their satisfaction with salary and working conditions, for example. On the other hand, studies suggest that emotions and moods at work, contemplated in affective measures, consist of the central dimension of well-being and are more strongly related to job performance (Demo \& Paschoal, 2016; Warr \& Nielsen, 2018).

Another gap in studies on the relationship between happiness and productivity concerns the level of analysis that is exclusively individual. There are a few studies at the group level, as concluded by the study by Peñalver, Salanova, Martínez, and Schaufeli (2019). The authors explain that happy groups are those that share positive emotions collectively and propose a psychosocial model in which these groups, in addition to being happy, are also more productive because they perform better at work. However, it is important to emphasize that this relationship is not always right, because for a group to be happy and productive at the same time, other variables may be immersed in this process, an example of which would be social resources (teamwork, coordination, cohesion, supportive team atmosphere) that produced a mediating effect on a happy, more productive group relationship.

From the organizational perspective about job performance antecedents, studies address workplace factors and motivational approaches or approaches focused on reward systems and perceived justice. In this sense, the experience of injustice, for example, affects not only the individual as a member of a social group but also the other members of that group (De Dreu \& Nauta, 2009). Most of the context factors related to this perspective (information need, stressors, machine problems, and supplements) are contemplated in the organizational support construct for performance (Eisenberger, Huntington, Hutchison, \& Sowa, 1986). Thus, the contextual variables investigated in this study were organizational support and organizational justice. 
Considering gaps in the relationship between well-being at work and job performance, the scarcity of multilevel studies to explain job performance and the importance of organizational variables, a multilevel design model was adopted for this study, in which, according to Puente-Palacios and Laros (2009), the understanding of a specific phenomenon implies the recognition of the existence of explanatory elements from different levels. Thus, this study starts from the premise that members of a team or sector exhibit similar behavior, that is, that there is an intragroup homogeneity. It is also assumed that the teams and/or sectors present different behaviors among each other, given the peculiarities of the activities and the routine of each one, being verified, therefore, an intergroup heterogeneity. The consideration of this proposition will enable a more accurate interpretation of the results of the proposed relations and contribute to the development of research productions dealing with the group level.

Therefore, based on the Hawthorne effect (Mayo, 1933) and in the hypothesis "happy, productive worker", the objective of this research is to analyze the predictive relationships, through a multilevel approach, between the variables well-being at work, organizational support, organizational justice, and the dependent variable individual job performance. This study sought to offer new theoretical and practical contributions to this phenomenon. It also contributes to identifying explanatory variables at the team level and the adoption of multilevel modeling in their analysis, aiming to understand in a more integrated and comprehensive way the nature of individual job performance.

\section{THEORETICAL FRAMEWORK AND RESEARCH HYPOTHESIS}

Based on the proposed objective and the literature review, hypotheses were made for each relationship between the variables provided in the objective.

\subsection{Well-being at work and individual job performance}

Well-being is one of those variables that have impacted the resulting performance (Judge \& Zapata, 2015; Nangov, Sasmoko, \& Indrianti, 2018). The so-called psychological well-being (PWB), understood by the presence of positive affect, the absence of negative affect, and the presence of satisfaction, 
seems to be an excellent way to promote individual and organizational success and good performance (Loon, Otaye-Ebede, \& Stewart, 2019).

Zheng, Zhu, Zhao, and Zhang (2015) explored the theoretical model and the structural dimensions of employees' well-being in organizations. After a series of quantitative studies, they found that employee well-being is significantly correlated with affective organizational commitment and job performance, with PWB as one factor of well-being at work. In the same line, Nangoy, Mursitama, Setiadi, and Pradipto (2020) showed that employees' well-being had a significant and positive effect on job performance.

According to Barsade and Knight (2015), group affect can influence the group's effectiveness and performance. Peñalver et al. (2019) indicate the influence of positive group affect on group job performance and the mediating role of the group's social resources, such as teamwork, coordination, cohesion, support team atmosphere. This study corroborated Knight and Eisenkraft's (2014) findings, which signaled that the way members relate in a group generated consistent positive effects on group job performance.

Yeo, Andrei, Hall, Tang, and Restubog (2019) pointed out that the high negative affect of the group may not be harmful to individuals if they fit the profile of a homogeneous negative group. In turn, about positive affect, the relationships that arose between the positive affect constructs of the group were consistent with previous studies. Groups characterized by high positive affect and low positive affective diversity were the ideal environments for positive individual performance levels.

Warr and Nielsen (2018) conducted a systematic review of the relationship between well-being at work and job performance at individual and group levels. Results suggest that individuals and groups with high wellbeing perform better in their jobs than those with lower well-being. About individual employees, the referenced authors indicate small or moderate cross-sectional and longitudinal associations between job satisfaction or affect and job performance. Considering the group-level well-being, the referenced authors describe moderate associations between group affective tone and job performance. Warr and Nielsen (2018) highlight the scarcity of studies at the group level and consider moderators of different levels in the explanatory models of job performance.

Considering work well-being as a collective phenomenon is a controversial issue. However, recent research has tried to explore this possibility, including the "happy, productive worker" hypothesis at the team level; results show it is entirely possible (García-Buades, Peiró, Montañez-Juan, Kozusznik, \& Ortiz-Bonnín, 2019). We can infer that the representations of 
well-being are human productions that are born and structured based on the experiences of employees in organizational contexts and assume specificities both in the forms of manifestation/consolidation (e.g., feeling happy for the recognition at work) and in dynamics of transformations that take place in the face of, for example, organizational innovations (e.g., content to assume new tasks). Starting from the premise that collectivity presupposes the sharing of beliefs, affects, and perceptions, the affect in the workplace can also be approached as a group phenomenon. In this way, we can infer that positive affects not only cover internal states that occur at the individual level, but also processes that occur between individuals, that is, at the group level (Barsade \& Knight, 2015; García-Buades et al., 2019; Peñalver et al., 2019; Warr \& Nielsen, 2018).

Although emotions and moods consist of the central dimension of wellbeing at work, the cognitive dimension related to the perception of achievement of individual goals and personal fulfillment complements the construct's definitions and broadens their understanding (Warr \& Nielsen, 2018). Therefore, in the present study, both a cognitive dimension of well-being (achievement) and emotions and moods at work (affects) are considered.

Considering the propositions and evidence found in the literature, the first and second hypotheses of this study were:

- H1: Well-being at work is positively associated with individual job performance.

- H2: Collective perceptions of well-being at work are positively associated with individual job performance.

\subsection{Organizational justice and individual job performance}

Organizational justice is based on the principle that the organization's treatment is essential to retain loyal employees and provide a good work environment (Aslam, Arfeen, Mohti, \& Rahman, 2015; Zeb, Abdullah, Othayman, \& Ali, 2019). Organizational justice is not only understood from the perception of the results but also the procedures adopted and the treatment received during the activities performed, culminating, therefore, in its three dimensions: distributive, procedural, and interactional (Cohen-Charash \& Spector, 2001). Nevertheless, authors such as Masterson, Lewis, Goldman, and Taylor (2000) point out that studies on organizational justice were developed from the perspective of job performance.

In this perspective, some studies have also pointed to this positive predictive relationship between organizational justice and individual job perfor- 
mance, with emphasis, in most studies, on the task performance (Aryee, Walumbwa, Mondejar, \& Chu, 2015; Janssen, Lam, \& Huang, 2010). In the study by Zeb et al. (2019), for example, it was found that the three dimensions of organizational justice (distributive, procedural, and interactional) generated both direct and indirect effects on individual job performance. In the indirect relationship, the LMX variable produces a moderating relationship, causing strong effects on justice and performance.

The study by De Dreu and Nauta (2009) brought the concept of "organizational justice climate", and their analysis provided evidence that individual job performance is a function of team-level attributes, such as the organizational justice climate when employees have a high "orientation to each other". The study by Siswanti, Tjahjono, Hartono, and Prajogo (2020) offered theoretical and empirical support for the concept of organizational justice climate in all its dimensions. Starting from the previous propositions, hypotheses 3 and 4 were elaborated:

- H3: Individual perception of organizational justice is positively associated with individual job performance.

- H4: Collective perceptions of organizational justice are positively associated with individual job performance.

\subsection{Organizational support and individual job performance}

According to Eisenberger et al. (1986), insofar as perceived organizational support meets the needs of praise and approval, the employee would incorporate organizational adherence to self-identity and develop a positive emotional bond (affective bond) with the organization. Affective bonding would expect to increase an individual's efforts to meet the organization's goals through greater participation and performance.

Hochwarter, Witt, Treadway, and Ferris (2006) provided an explanation for the increased relationship between perceived organizational support and individual job performance based on the social exchange theory. The authors considered the perception of organizational support in terms of resource allocation and suggested that organizational support provides resources that allow employees to achieve organizational goals. An employee who reports a high perception of organizational support may perceive that management is positioning itself for the employees to succeed, providing sufficient resources, and facilitating cooperation through recognition and rewards.

Wallace, Edwards, Arnold, Frazier, and Finch (2009) conceived organizational support as a model of direct consensus aggregation. For organiza- 
tional support, the interaction between the members of a unit serves to strengthen the collective organizational support through repeated cycles of individual interactions and influences, thus, codifying a group norm, acting on the perceived organizational support. As for the multilevel effect, the study by Chang, Liu, Hsieh, and Chen (2020), contributed by proposing the analysis of organizational support at different levels of analysis (individual, groups, and organizational) and pointed out that organizational support positively impacts the job performance of university teachers of physical education. Based on these considerations, hypotheses 5 and 6 were constructed:

- H5: Individual perceived organizational support is positively associated with individual job performance.

- H6: Collective perceived organizational support is positively associated with individual job performance.

Therefore, this model can be considered as multilevel since it presents theoretical relations hypothesized between individual-level variables and team-level variables as well as their interactions in relation to the prediction of the dependent variable individual job performance, situated at the individual level.

It is essential to clarify that the present study intends to control some characteristics related to the demographic and functional profile of the sample in order to verify the other sources of variation among the units investigated. It was considered a model with variables contained in two levels of analysis. At the first level are the individuals. These were grouped into work units, which correspond to the second level of analysis. Thus, based on the assumptions of multilevel modeling, this study starts from three assumptions, namely:

1. The social grouping of two or more individuals is defined as a team (see Klein \& Kozlowski, 2000).

2. The definition of collective (or shared) perceptions assumes that every team is able to share perceptions by virtue of something, culminating in social identity (Klein \& Kozlowski, 2000).

3. Perceptions provide empirical foundations for understanding individual job performance (Klein \& Kozlowski, 2000).

Using the statistical technique of aggregation of individual perceptions (calculating the mean), it was possible to measure the team-level variables, that is, the collective perceptions. Thus, we have as team-level variables: collective perceptions of well-being at work, collective perceptions of organizational support, and collective perceptions of organizational justice. 
As it will be explained in the section "Method", multilevel modeling requires the analysis of interaction terms. Thus, interactions between variables belonging to both individual and team levels were tested, as indicated by Hox, Moerbeek, and Schoot (2017), because the effect produced separately by these variables may differ from their interaction with others at the same or at distinct levels. Thus, interactions between the independent variables proposed in the theoretical model were tested, relating well-being at work factors, organizational justice factors, organizational support factors, and personal and professional characteristics, measured both at the same level and in cross-level interactions, relating variables from level 1 to level 2. Such interactions were undertaken with the purpose of adjusting the multilevel model, and it is not necessary to propose hypotheses for these relationships.

\section{METHOD}

\subsection{Participants}

To test the proposed model, an organization (named here as Bank) was selected to compose the scope to be searched. Its organizational structure counts on more than 100 thousand employees spread in agencies throughout Brazil. Aiming to assure units with similar organizational structures, we chose to collect the data at Bank branches distributed throughout the country. There were 1290 questionnaires answered by the Organization's employees. After the data treatment, the final sample consisted of 730 participants. The results indicate that the average age of the participants is 41 years old. There is a slight predominance of men, representing $59.6 \%$ of the sample. Most of the participants $(43.4 \%)$ have completed higher education, and the average service time is 12 years. About the job position, it is verified that the majority is composed of clerks $(24.2 \%)$, followed by the relationship managers, who represent $22.9 \%$ of the respondents.

\subsection{Instruments}

To reach the objectives proposed by the research, we choose four instruments that were already demonstrated validity evidence and are widely used in Brazilian literature, which is why they should be in line with the reality of the organization studied. In the most recent version (Fogaça, Coelho, \& Hollanda, 2016), the Self-Assessment Measurement of Job Performance 
had two factors: "strategies oriented to individual job performance" (22 items, $\alpha=0.96$ ) and "contextual performance" (five items, $\alpha=0.70$ ). The Well-Being at Work Scale (Demo \& Paschoal, 2016), with three factors: "positive affect" (nine items, $\alpha=0.93$ ), "negative affection" (12 items, $\alpha=$ 0.91 ) and "realization" (nine items, $\alpha=0.88$ ). The Organizational Justice Perception Scale (Mendonça, Pereira, Tamayo, \& Paz, 2002) includes the three dimensions of organizational justice: "distributive justice" (six items), "procedural justice" (seven items), and "interactional justice" (seven items) of Cronbach's alphas ranging from 0.87 to 0.89 . The Perceived Organizational Support Scale, in its reduced version (Brandão, 2009), had four factors: "performance management" (seven items, $\alpha=0.87$ ), "workload" (seven items, $\alpha=0.85$ ), "material support to performance" (six items, $\alpha=$ 0.91), and "promotions, rise and wages" (eight items, $\alpha=0.85$ ).

It is important to bear in mind that the interpretation of all variables individually would be quite difficult; for this reason, the number of variables in the scales of well-being at work, organizational support, and organizational justice were reduced using the factors proposed in the adopted scales. Therefore, the objective is to reduce data allowing a greater number of variables to be reduced to a smaller set of parameters that have variability and reliability (Brandão, 2009; Coelho, 2009).

Although well-being at work, organizational justice, and organizational support scales are widely used in the literature, we decided to carry out the principal component analysis (PCA) to observe the behavior of these scales for the sample used in this research. After observing the items combined in each factor, we identified that they were exactly the same as the proposal by the authors of each scale. Also, following the same premise, as job performance is a context-dependent construct, as well as such a scale is in the process of validation, and its use in previous studies has demonstrated several factor combinations, it has also been subjected to a PCA in order to assess the structure that the scale presented for the studied sample. Also, we identified the same two factors from the original scale. Nevertheless, for all four scales, the reliability indexes were above 0.7 (as previously expressed), indicating appropriate convergence, and factor loads greater than 0.5 indicate the convergent validity of the scale (Hair et al., 2009).

\subsection{Data collection procedures}

To meet the proposed objectives, a survey was conducted in an organization called Bank. The data collection strategy was structured based on a 
questionnaire composed of four scales, each related to a research variable. The questionnaire also had questions about the respondent's socio-demographic data, such as age, gender, education level, length of service, and type of position, which will be referred to in this paper as personal and professional variables and had the function of control variables. As mentioned earlier, the survey's target audience was Bank agencies; thus, it was decided to trigger them via functional e-mail to reach all branches in all regions of the country.

\subsection{Data analysis procedures}

The data from the application of the questionnaires were migrated to the Statistical Package for Social Sciences (SPSS) program, thus starting the data processing stage, including the analysis of frequency distribution, missing values, and outliers. The multilevel model investigated must meet the assumptions of normality, parsimony, and linearity. The analysis of variance and covariance allows us to verify the effects of variables belonging to both individual and group levels in relation to some predicted criterion variable, as well as the size of the associated error (Coelho, 2009).

To ensure the robustness of the results for the application of the multilevel analysis, the data treatment for the organization sample was carried out. The data collection lasted three months, reaching a total of 1,290 answered questionnaires. Following the guidelines of Tabachnick and Fidell (2019), in order to verify questionnaires with missing data, the listwise procedure was used, allowing the elimination of subjects that presented some blank value. Following these criteria, 293 responses of subjects from the Bank were identified. It is noteworthy that, after identifying these missing values, it was found that they were individuals who abandoned filling out the questionnaire, leaving at least one of the scales with all items blank. Thus, it was decided to remove them from the study. Then, the extreme multivariate cases were identified through the Mahalanobis distance. The chisquare table was used as the verification base for the sample of the organization, with a significance index of $\mathrm{p}<0.001$, obtaining the value of $\mathrm{X}^{2}=$ 124.8. Thus, after this stage, 267 subjects were removed. It is important to emphasize that analyzes were also carried out with a sample with outliers to identify whether these subjects would be figures with influential organization roles. However, the analysis results with the treated samples (that is, without missing values and outliers) proved to be more interesting, and all the following steps describe the results obtained with this sample. In the end, the total sample of the Bank consisted of 730 subjects. 
In the case of the Organization, it was decided to work with the Bank's branches, which are spread throughout the country. Due to the organizational structure that these agencies have and the interconnection among agencies located in the same region, the units were defined based on the organization's regional segmentation (state superintendencies). This segmentation considers all Brazilian capitals, with the city of São Paulo subdivided into three. Some cities or municipalities have so much expression that they are considered separately, such as Campinas, and the municipalities of São Paulo state are considered a separate unit from São Paulo capital, as well as the cities in the state of Minas Gerais that are also treated differently from Belo Horizonte (the capital). These clusters have seven to 85 individuals allocated. Therefore, in this study, the units of the organization B totaled 32: the 27 Federation Units, plus two units in the capital of São Paulo, the unit in Campinas, the group of municipalities in São Paulo state, and the group of cities in Minas Gerais, which represented the highest level. In this case, the minimum size established for the formation of each team was the participation of seven individuals. In addition, considering the proposed multilevel analysis, working with a sample of ten units at the macro level would be as uncomfortable as doing a regression analysis, considering only the responses of ten individuals (Puente-Palacios \& Laros, 2009). Distinguishing the types of existing positions, it is observed that all areas have a similar structure, with clerks, executive officers, relationship managers, unit managers, and assistants. This diversity ensures the heterogeneity of the studied group and meets Puente-Palacios and Laros' (2009) guidelines on multilevel studies. Due to the organizational structure that branches have and the interconnection between agencies located in the same region, the units were defined based on the regional segmentation made by the Organization itself (state superintendencies), totaling 32 units. In this case, the minimum size established for the formation of each team was the participation of seven individuals.

The MLwiN software was used to develop this study. It is important to note that the data were analyzed based on the six steps of Hox (Hox et al., 2017) and that these steps were executed for each of the job performance factors, meaning that each job performance factor would be a dependent variable. In the end, it is expected to verify how much of the variability of the dependent variable "individual job performance" will occur due to the size of the effect of each antecedent variable, analyzed alone or in interaction with variables of the same level and of differentiated levels. 


\section{RESULTS}

Two multilevel models were tested, one for each dependent variable, i.e., one for each job performance factor. Thus, a model was tested to verify the predictors of the factor "strategies oriented to individual performance" and another one to identify predictors of "contextual performance". However, it should be noted that some methodological procedures were adopted in order to make feasible the application of Hox et al.'s (2017) steps in achieving the objective of the present research. Firstly, we opted for the aggregation method for the construction of the units. For this, the team-level variables (units) were aggregated by the calculation of their means. In this research, each of the studied constructs' factors correspond to the studied variables; this way, we have ten variables of team-level.

As proposed by Hox et al. (2017), it is necessary to analyze the initial estimates of variance at both the individual and team levels, as well as the intraclass correlation coefficient (ICC). The organization sample showed interesting behavior since the results were different for each of the variables. For the first factor, "strategies oriented to individual performance", despite presenting a positive deviance value, the value of the ICC was zero. In turn, the variable "contextual performance" presented satisfactory results, with its initial estimate of positive deviance and the ICC equal to 0.12. This means that $12 \%$ of this dependent variable's total variance would be due to the team level, demonstrating that being crowded in a certain company unit has a significant effect on this individual's contextual performance. Therefore, this result justifies the adoption of multilevel analysis, according to the proposal of this research. Thus, the following steps were developed only for the variable "contextual performance".

Even in the first step of Hox et al. (2017), the empty model is calculated, which showed a deviance estimate for the empty model equal to 2,069.957, so that this value will be the parameter for testing the following models. This means that, after the insertion of each variable, it will be observed if the deviance will show a reduction in its value. If this drop occurs, it means an improvement in the model's fit, indicating that the model chosen should be the one with the lowest deviance, according to Snijders and Bosker's (2011) recommendations.

In the second step, the control variables, individual-level, and team-level were added to the model. In this study, the control variables adopted were socio-demographic variables: age (individual-level), length of service (individual-level), level of schooling (individual-level), the aggregate level of 
schooling (team-level), job position (individual-level), aggregate job position (team-level). The inclusion of such variables is justified by the objective of controlling the effect of these variables on contextual performance.

After inserting the control variables, only recoded job position and standardized age were significant $(t<2)$ for model 2. Comparing the deviance obtained in model 2, with the value of 2,048.480, with that of the empty model $(2,069.957)$, a reduction in value is noticeable, indicating a better fit of the present model. Following Hox et al.'s (2017) proposition, in this step, we insert the variables of the individual-level. Regarding the variables inserted in model 3, achievement, interactional justice, and distributive justice, they presented significance $(t<2)$. Observing the models' deviance one more time, a significant reduction of the index from model 2 to model 3 is observed, from $2,048.480$ to $1,828.093$.

For the construction of model 4 , the team-level variables were inserted, and collective perceptions of performance management practices and collective perceptions of workload, both from the organizational support construct, were the only ones that contributed significantly $(t<2)$ to the explanation of contextual performance. The adjustment of this model compared to the previous model (model 3) was significant since the deviance value fell from $1,828.093$ to $1,799.723$. In addition, an important fact must be mentioned: the individual-level variable distributive justice, until then significant, lost significance in model 4 , with the insertion of team-level variables. This fact is not surprising if it is based on the assumptions of Hox et al. (2017), which expresses that the effects of each variable acquire new values for each theoretical model, considering the shared variance between the tested variables, their regression coefficients, and associated errors, besides its impact on the prediction of the dependent variable.

In the next step, the individual variables with random parameters were included in the model. The adoption of such variables makes sense since the slopes of the independent variables have significant components of variance between the teams, thus, differing in their composition. Despite the importance of this step, the random effect variables inserted in model 5 did not present any significant contribution. Nevertheless, when inserting such variables, the deviance value had an increase when compared to the previous model, going from $1,799.723$ to $1,848.962$. In short, there was no inclusion of variables in this step.

The last step or Hox et al.'s (2017) sixth step consists of the inclusion of the terms of interaction because the interaction presupposes that the multiplier effect of the variables may influence the prediction of the associated 
dependent variable. It is also emphasized that the variables in interaction have different effects when they are inserted separately. For the construction of interaction terms, a correlation analysis was made between all explanatory variables, both the individual-level and the team level. The scores that presented the most significant correlations were inserted as terms of interaction. Based on this procedure, two terms of interaction were significant for model 6: "achievement with collective perceptions of interactional justice" and "distributive justice with collective perceptions of performance management practices". All other interactions involving variables of the same level and cross-level variables were not significant $(t<2)$.

It was also verified that there was a deviance reduction, from $1,828.093$ in the previous model (in this case, model 4) to 1,786.767 in the final model. This result shows that model 6 presents the best fit in relation to the data. In turn, the interactions show that the effect of achievement is more significant when there are shared perceptions of interactional justice; in addition, the data show that the distributive justice effect is more significant when there are shared perceptions of performance management practices. Figure 4.1 summarizes the results of models $1,2,3,4,5$, and 6 .

At the end of the multilevel analysis for the sample of the organization, the explanatory model for the variable "contextual performance" presents that the factors achievement, interactional justice, age, job position, collective perceptions of performance management practices and collective perceptions of workload, besides the terms of the interaction "achievement versus collective perceptions of interactional justice" and "distributive justice versus collective perceptions of performance management practices" are predictors of the dependent variable "contextual performance". 


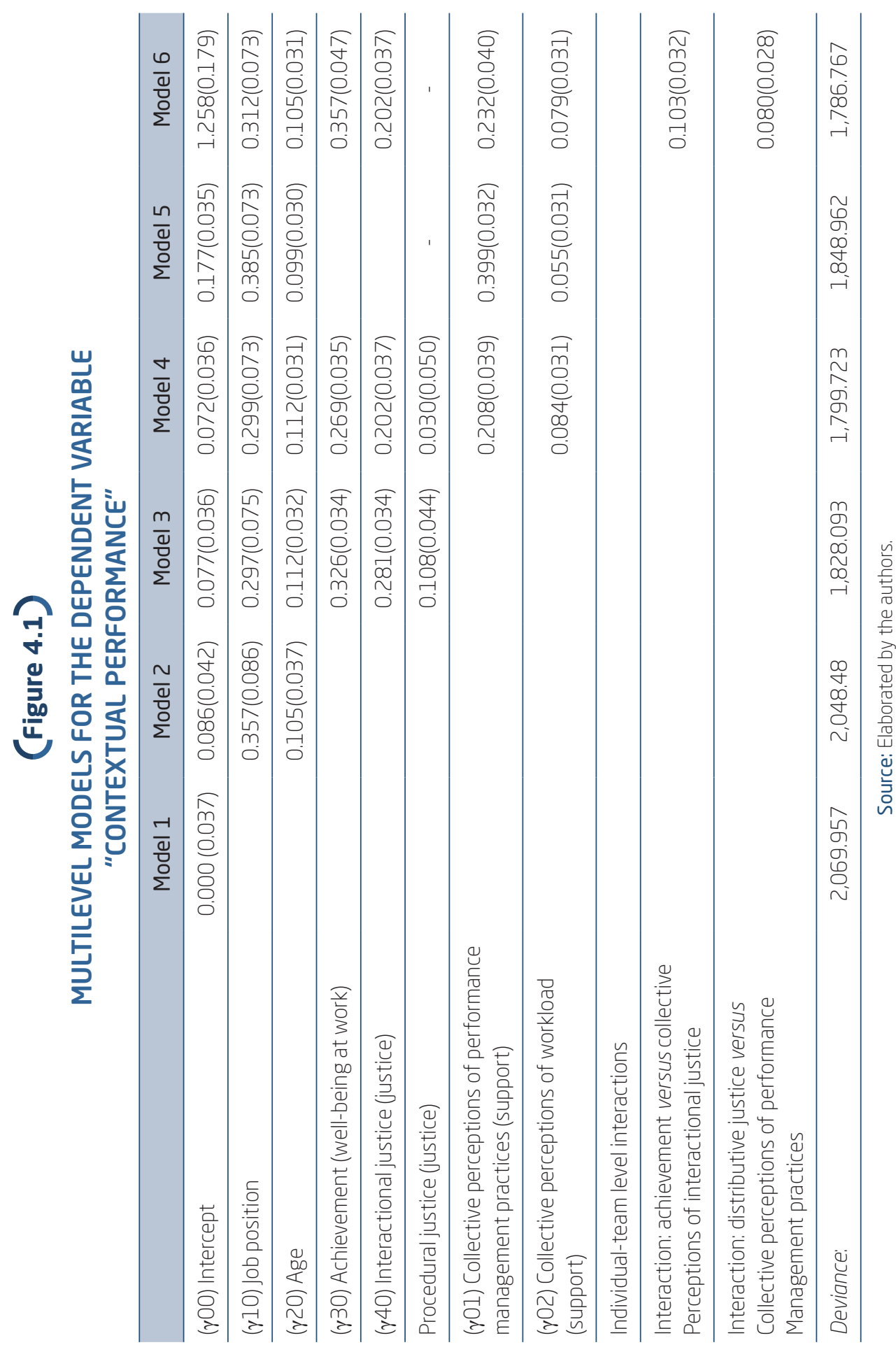




\section{DISCUSSION}

The present study identified predictive relationships of variables at individual and team levels with individual job performance. An interesting fact of the relationships found is that the results showed that variables traditionally studied at the individual level actually remained at this level to explain individual job performance, such as well-being at work and organizational justice. In turn, organizational support, traditionally understood as a context variable but traditionally studied under the individual perception, appeared at the group level, reinforcing the evidence that organizational support really should be worked at levels above the individual level.

Firstly, the multilevel model pointed to the predictive relation between achievement (well-being at work factor) and contextual performance. In this case, only the $\mathrm{H} 1$ hypothesis has been confirmed that well-being at work is positively associated with individual job performance. Finding the achievement factor as a predictor, this study corroborates Zheng et al.'s (2015) and Loon et al.'s (2019) studies, who found a significant PWB as one of its factors.

In turn, H2 was not confirmed, which proposed that collective perceptions of well-being at work would be positively associated with individual job performance. Although the existence of collective perceptions of wellbeing at work was defended here and the results of the generated multilevel model do not demonstrate a predictive relationship between collective perceptions of well-being at work and individual job performance, this does not mean that they do not exist in the organizational environment. Nonetheless, this result brings out important evidence that well-being at work does indeed appear to be an individual-level variable since collective perceptions were not significant in explaining performance. A possible explanation may be supported by Barsade and Knight (2015), who explains that the affect of groups can influence, among other aspects, the effectiveness and performance of the group. While here, in this research, the proposal was to relate team-level well-being to individual job performance.

About organizational justice, only the $\mathrm{H} 3$ hypothesis has been confirmed. This hypothesis proposed that the individual perception of organizational justice would be positively associated with individual job performance, being confirmed with the multilevel model. The interactional justice dimension has proved to be a predictor of individual job performance. This result demonstrates the premise based on the theory of social exchange, 
that when the measure of job performance is influenced by the relationship between the employee and his/her supervisor, there is a relationship between job performance and interactional justice (Masterson et al., 2000).

Given these results, it is possible to infer that respondents' focus in assessing contextual performance was based on superior-subordinate relationships, so that when employees perceive that they are treated fairly by managers or when they are satisfied with their managers, they perform better (Cohen-Charash \& Spector, 2001; Masterson et al., 2000). In addition, the present finding is relevant since, in the recent literature, the interactional dimension (and its sub-dimensions, informational and interpersonal) is not usually considered as a single dimension to measure organizational justice.

Collective perceptions of organizational justice, in turn, did not establish predictive relationships with individual job performance, thus not confirming hypothesis H4. Although it does not appear in a direct relationship in the model, collective perceptions of justice appear in one of the interaction terms (predictors of performance), which can be understood as an opportunity for analysis on how organizational justice is perceived at the team level.

Thus, the individual perception is of realization, but before the group, there is the perception of injustice and vice versa. Translated, it can be said that when an employee feels that he/she develops his/her potentials and reaches his/her goals before the group, there is a perception that the superior does not offer proper treatment to his/her subordinates.

This result is not surprising when compared to the study of Janssen et al. (2010), who realized that when there was a low perception of distributive justice, there was a negative relationship between emotional exhaustion and job performance. Although addressing different dimensions, both studies show that the interaction between well-being at work and organizational justice leads to a more or less favorable perception of performance.

Following the trend of the other variables, two hypotheses were also proposed for the relationship between organizational support and individual job performance, considering individual and collective perceptions. Also, as with the previously treated variables, only one of these hypotheses was confirmed. However, unlike the others, in this case, the refuted hypothesis was $\mathrm{H} 5$, related to individual perceptions, which proposed that individual perception of organizational support would be positively associated with individual job performance.

$\mathrm{H} 6$ was confirmed when the collective perceptions of the organizational support dimensions (workload and management performance practices) 
appeared in the multilevel model as predictors of individual job performance. In addition, collective perceptions of organizational support appeared in one of the terms of interaction, in which the relationship between distributive justice and collective perceptions of performance management practices contributed to the explanation of contextual performance.

These results corroborate previous studies that have demonstrated that such dimensions, workload (Beck \& Schmidt, 2013) and performance management practices (Lam, Peng, \& Lau, 2015; Li, Harris, Boswell, \& Xie, 2011; Ozer, 2011; Rubin, Dierdoff, \& Bachrach, 2013), had a direct and predictive relationship with individual job performance. Identifying the collective perceptions of organizational support as explanatory factors of the performance variable, it is possible to argue that this is one of the main contributions of this study. Since organizational support is a traditionally context variable but commonly studied under the individual's aegis, it was not possible to understand its relevance at the team and organizational levels.

An interesting result identified in the organization is that collective perceptions about workload were positively related to individual job performance. This is in contrast to that found in the literature, as in Beck and Schmidt's study (2013), for example, in which the perception of time pressure (an aspect of the workload) was negatively related to the objective orientation state. This study, however, dealt with the variables at the individual level. It is noteworthy that Beck and Schmidt (2013) found that the relationship between time pressure and performance is mediated by objective orientations. Thus, it is possible to assume that higher workloads are associated with the organization's challenging goals and require greater energy and commitment from professionals.

The interaction between organizational support and organizational justice identified in the term of interaction between distributive justice and collective perceptions of performance management practices deserves attention. It is important to emphasize that the relationship between them is direct, which makes a total theoretical sense as pointed by the definition of Rêgo (2002), in which distributive justice is linked to the perception of individuals in relation to wages, that is, the classifications obtained by the performance, promotions, distributed profits, and disciplinary sanctions. Therefore, when the individual realizes that the performance evaluation was fair, his/her perception in the team is that performance management practices are positive.

What implications do these findings bring to the understanding of teams in the organizational context? By finding such evidence of the relationship 
between collective perceptions of organizational support and individual job performance, it is possible to see not only the predictive relation but the confirmation that the units studied are actually teams. And in the case of collective perceptions about performance management practices, it is evident that in the group's view, positive perception of such practices leads to positive performance; thus, the individual incorporated into teams with such perception ends up presenting more favorable perceptions of their performance. According to Lakatos and Marconi (2019), social interaction encompasses meanings and expectations in relation to others' actions, so that it is possible to say that interaction is the reciprocity of social actions. For this reason, speaking in collective perceptions, and more specifically in the psychological content that it brings with it, it is possible to infer that there are differences of intensity and strength in relation to the phenomena observed.

According to the previous inference, we can think of shared perceptions of organizational support as a collective construct because it was defined based on its function. Proceeding in this way, it was possible to speak in organizational support at the team level since both the individual perceptions and the collective perceptions of organizational support have the same function. Obtaining a multilevel model and predictive relations of variables at the collective level also ratifies the construct's validity and the significance of the higher-level construct that results from the process (Klein \& Kozlowski, 2000).

The model obtained in this research seems to be based on the theory of reciprocity (Gouldner, 1960), in which individual job performance is a way for the employee to return to the organization for the good treatment offered by it. According to the premises of social reciprocity, we can understand that the Organization's employees understand that they are the recipients and the organization is the donor, given the predictive relationship found here. These beliefs, on the part of the employee, contribute to constructing their social identity by taking this relationship of social exchange as a basis. This is because the individual identifies himself or herself as a beneficiary, and the organization is identified by him/her as a social source of support. Therefore, in the present study, one has to say that the expected performance of an individual is related to the perception that he/she and his/her team have of organizational support, organizational justice, and well-being at work. 


\section{CONCLUSION}

The objective of analyzing the predictive relationships, through a multilevel approach, between the variables well-being at work, organizational justice, organizational support, and the variable individual job performance was fulfilled since the multilevel model found demonstrated such interactions. It is precisely in the identification of the predictive effect of collective perceptions of organizational support that the main contribution of this study lies. This contribution is not limited to the statistical relationship that is currently encountered, but because of the implications regarding the role of teams in the individuals' job performance and the way in which the individual perceives the organizational reality. As discussed earlier, the sense of social identity that emerges from the fact that the individual feels part of a group may be the key to understanding the so-called organizational identity.

Although the results of this research are significant for providing evidence of the representativeness of work teams for individual job performance, the composition of the teams constitutes a limitation for the generalization of the results. As described previously, the teams were formed based on the Bank's geographical segmentation, reflecting a specificity of its organizational context. Also, it was not possible to have information about the composition of the teams, focusing on aspects of social interaction patterns. However, in order to understand the specificities of units and teams, the adoption of qualitative methods in the study of team-level variables can help identify the teams in which there is greater cohesion in the sharing of perceptions and in the more fragmented teams with little cohesion between perceptions.

Notwithstanding the theoretical contributions in this sense, the results of this research indicated that employee well-being should be a pressing concern of managers and their organizations in view of the desired positive performance by their employees. Practices that address working conditions may deserve the most attention, as they focus on protecting and caring for employees in terms of benefits, health, safety, and technology. Since workload has shown a relevant role in individual job performance, it is recommended that organizations review their employees' workload based on the activities performed by teams, particularly by investigating what aspects of the organization's culture lie behind the collective perceptions of units in relation to workload. 


\section{RELAÇÕES ENTRE DESEMPENHO, BEM-ESTAR NO TRABALHO, JUSTIÇA E SUPORTE ORGANIZACIONAL: UMA PERSPECTIVA MULTINÍVEL}

\section{RESUMO}

Objetivo: Esta pesquisa foi baseada na hipótese do "trabalhador feliz, produtivo". O objetivo foi analisar as relações preditivas, por meio de abordagem multinível, entre as variáveis bem-estar no trabalho, justiça organizacional e suporte organizacional e a variável critério desempenho individual no trabalho.

Originalidade/valor: O estudo multinível do desempenho no trabalho e suas relações com bem-estar e variáveis organizacionais ainda são uma lacuna atual na literatura, assim como a possibilidade de testar se o bem-estar no trabalho pode ser considerado um fenômeno coletivo. A presença do suporte organizacional no modelo, operacionalizado em nível de equipe, representa uma importante contribuição, assim como para o desenvolvimento de teorias voltadas para o papel das equipes nas organizações, especialmente seu impacto nas variáveis organizacionais. Design/metodologia/abordagem: Considerando a análise proposta em dois níveis diferentes, adotou-se um modelo multinível. A amostra final foi composta por 730 indivíduos e 32 unidades. Coletaram-se os dados por meio de questionário composto por quatro escalas previamente validadas. A análise dos dados seguiu as seis etapas propostas por Hox, Moerbeek e Schoot (2017) para modelos multiníveis para cada uma das amostras.

Resultados: O modelo explicativo apresentou uma relação preditiva entre realização (fator de bem-estar no trabalho), operacionalizada como variável de nível individual, e desempenho individual do trabalho; relação preditiva entre justiça interacional, também operacionalizada como variável individual, e desempenho individual do trabalho; e relação preditiva entre as percepções coletivas de suporte organizacional, operacionalizada como variável de nível de equipe, e desempenho individual do trabalho. 


\section{PALAVRAS-CHAVE}

Percepções coletivas. Desempenho individual no trabalho. Bem-estar no trabalho. Justiça organizacional. Suporte organizacional.

\section{REFERENCES}

Aryee, S., Walumbwa, F. O., Mondejar, R., \& Chu, C. W. L. (2015). Accounting for the influence of overall justice on job performance: Integrating selfdetermination and social exchange theories. Journal of Management Studies, 52(2), 231-252.

Aslam, U., Arfeen, M., Mohti, W., \& Rahman, U. (2015). Organizational cynicism and its impact on privatization (evidence from federal government agency of Pakistan). Transforming Government: People, Process and Policy, 9(4), 401-425.

Barsade, S. G., \& Knight, A. P. (2015). Group affect. Annual Review of Organizational Psychology and Organizational Behavior, 2, 21-46.

Beck, J. W., \& Schmidt, A. M. (2013). State-level goal orientations as mediators of the relationship between time pressure and performance: A longitudinal study. Journal of Applied Psychology, 98(2), 354-363.

Brandão, H. P. (2009). Aprendizagem, contexto, competência e desempenho: Um estudo multível ((Tese de doutorado, Universidade de Brasília). Retrieved from https://repositorio.unb.br/handle/10482/8322

Chang, C., Liu, L., Hsieh, H., \& Chen, K. (2020). A multilevel analysis of organizational support on the relationship between person-environment fit and performance of university physical education teachers. International Journal of Environmental Research and Public Health, 17, 2041-2058.

Coelho, F. A., Jr. (2009). Suporte à aprendizagem, satisfação no trabalho e desempenho: Um estudo multinível (Tese de doutorado, Universidade de Brasília). Retrieved from https://repositorio.unb.br/handle/10482/8322

Cohen-Charash, Y., \& Spector, P. E. (2001). The role of justice in organizations: A meta-analysis. Organizational Behavior and Human Decision Processes, 86(2), 278-321. 
De Dreu, C. K. W., \& Nauta, A. (2009). Self-interest and other-orientation in organizational behavior: Implications for job performance, prosocial behavior, and personal initiative. Journal of Applied Psychology, 94, 913-926.

Demo, G., \& Paschoal, T. (2016). Well-being at work scale: Exploratory and confirmatory validation in the USA. Paidéia, 26(63), 35-43.

Eisenberger, R., Huntington, R., Hutchison, S., \& Sowa, D. (1986). Perceived organizational support. Journal of Applied Psychology, 71 (3), 500-507.

Fogaça, N., Coelho, F. A., Jr., \& Hollanda, P. P. T. M. (2016). Evidências de validade da escala de auto-avaliação de desempenho no trabalho. Congresso Brasileiro de Psicologia Organizacional e do Trabalho, Brasília, DF, Brasil, 7.

García-Buades, M. E., Peiró, J. M., Montañez-Juan, M. I., Kozusznik, M. W., \& Ortiz-Bonnín, S. (2019). Happy-productive teams and work units: A systematic review of the "happy-productive worker thesis". International Journal of Environmental Research and Public Health, 17(1), 69-108.

Gouldner, A. W. (1960). The norm of reciprocity: A preliminary statement. American Sociological Review, 25, 161-178.

Guerci, M., Hauff, S., \& Gilardi, S. (2019). High performance work practices and their associations with health, happiness and relational well-being: Are there any tradeoffs? The International Journal of Human Resource Management, 1-31.

Hair, J. F., Black, W. C., Babin, B. J., Anderson, R. E., \& Tatham, R. L. (2009). Análise multivariada de dados. Porto Alegre: Bookman Editora.

Hauff, S., Guerci, M., \& Gilardi, S. (2020). Well-being-oriented HRM configurations: Diffusion, contingencies and outcomes. Evidence-based HRM, 8(3), 253-271.

Hochwarter, W. A., Witt, L. A., Treadway, D. C., \& Ferris, G. R. (2006). The interaction of social skill and organizational support on job performance. Journal of Applied Psychology, 91 (2), 482-489.

Hox, J. J., Moerbeek, M., \& Schoot, R. (2017). Multilevel analysis: Techniques and applications. Abingdon, UK: Routledge.

Janssen, O., Lam, C. K., \& Huang, X. (2010). Emotional exhaustion and job performance: The moderating roles of distributive justice and positive affect. Journal of Organizational Behavior, 31 (6), 787-809.

Judge, T. A., \& Zapata, C. P. (2015). The person-situation debate revisited: Effect of situation strength and trait activation on the validity of the Big Five Personality Traits in predicting job performance. Academy of Management Journal, 58(4), 1149-1179.

Klein, K., \& Kozlowski, S. (2000). Multilevel theory: Research and methods in organizations. San Francisco: Jossey-Bass. 
Knight, A. P., \& Eisenkraft, N. (2014). Positive is usually good, negative is not always bad: The effects of group affect on social integration and task performance. Journal of Applied Psychology, 100(4), 1214-1227.

Lakatos, E. M., \& Marconi, M. A. (2019). Sociologia geral. São Paulo: Atlas.

Lam, L. W., Peng, C. W., \& Lau, D. C. (2015). Is more feedback seeking always better? Leader-member exchange moderates the relationship between feedback-seeking behavior and performance. Journal of Management, 43(7), 2195-2217.

Li, N., Harris, T. B., Boswell, W. R., \& Xie, Z. (2011). The role of organizational insiders' developmental feedback and proactive personality on newcomers' performance: An interactionist perspective. Journal of Applied Psychology, 96(6), 1317-1327.

Loon, M., Otaye-Ebede, L., \& Stewart, J. (2019). The paradox of employee psychological well-being practices: An integrative literature review and new directions for research. The International Journal of Human Resource Management, 30(1), 156-187.

Masterson, S. S., Lewis, K., Goldman, B. M., \& Taylor, M. S. (2000). Integrating justice and social exchange: The differing effects of fair procedures and treatment on work relationships. Academy of Management Journal, 43 (4), 738-748.

Mayo, E. (1933). The human problems of an industrial civilization. New York: The Macmillan Company.

Mendonça, H., Pereira, C., Tamayo, A., \& Paz, M. G. T. (2002). Validação fatorial de uma escala de percepção de justiça organizacional. Estudos, Saúde e Vida, 30(1), 111-130.

Nangov, R., Sasmoko, S., \& Indrianti, Y. (2018). Psychological capital, work well-being, and job performance. International Journal of Engineering $\mathcal{E}$ Technology, 7(4.9), 63-65.

Nangoy, R., Mursitama, T. N., Setiadi, N. J., \& Pradipto, Y. D. (2020). Creating sustainable performance in the fourth industrial revolution era: The effect of employee's work well-being on job performance. Management Science Letters, 10(5), 1037-1042.

Ozer, M. (2011). A moderated mediation model of the relationship between organizational citizenship behaviors and job performance. Journal of Applied Psychology, 96(6), 1328-1336.

Peñalver, J., Salanova, M., Martínez, I. M., \& Schaufeli, W. B. (2019). Happyproductive groups: How positive affect links to performance through social resources. The Journal of Positive Psychology, 14(3), 377-392. 
Puente-Palacios, K. E., \& Laros, J. A. (2009). Análise multinível: Contribuições para estudos sobre efeito do contexto social no comportamento individual. Estudos de Psicologia, 26(3), 349-361.

Rêgo, A. (2002). Comprometimento afetivo dos membros organizacionais: o papel das percepções de justiça. Revista de Administração Contemporânea, 6(2), 209-241.

Rubin, R. S., Dierdoff, E. C., \& Bachrach, D. G. (2013). Boundaries of citizenship behavior: Curvilinearity and context in the citizenship and task performance relationship. Personnel Psychology, 66 (2), 377-406.

Siswanti, Y., Tjahjono, H. K., Hartono, A., \& Prajogo, W. (2020). Organizational justice climate: Construct measurement and validation. Test Engineering and Management, 82, 8574-8590.

Snijders, T. A. B., \& Bosker, R. (2011). Multilevel analysis: An introduction to basic and advanced multilevel modeling. London: Sage.

Tabachnick, B. G., \& Fidell, L. S. (2019). Using multivariate statistics. New York: Harper \& Row Collins College.

Wallace, J. C., Edwards, B. D., Arnold, T., Frazier, M. L., \& Finch, D. M. (2009). Work stressors, role-based performance, and the moderating influence of organizational support. Journal of Applied Psychology, 94(1), 254-262.

Warr, P., \& Nielsen, K. (2018). Wellbeing and work performance. In E. Diener, S. Oishi, \& L. Tay (Eds.), Handbook of well-being. Salt Lake City, UT: DEF.

Yeo, G., Andrei, D., Hall, S. E., Tang, R. L., \& Restubog, S. L. D. (2019). We do not exist in an affective vacuum! Cross-level effects of trait affect and group affective properties on individual performance. Journal of Vocational Behavior, 112, 325-343.

Zeb, A., Abdullah, N. H., Othayman, M. B., \& Ali, M. (2019). The role of LMX in explaining relationships between organizational justice and job performance. Journal of Competitiveness, 11 (2), 144-160.

Zheng, X., Zhu, W., Zhao, H., \& Zhang, C. (2015). Employee well-being in organizations: Theoretical model, scale development, and cross-cultural validation. Journal of Organizational Behavior, 36(5), 621-644.

\section{AUTHOR NOTES}

Natasha Fogaça, Ph.D. from the Post Graduate Program in Business Administration (PPGA), University of Brasília (UnB); Francisco A. Coelho Junior, Ph.D. from the Post Graduate 
Program in Social, Work and Organizational Psychology (PSTO), UnB; Tatiane Paschoal, Ph.D. from the PSTO, UnB; Mario C. Ferreira, Ph.D. from the Department of Ergonomics, École Pratique des Hautes Études (Ephe); Camila C. Torres, Ph.D. from the PSTO, UnB.

Natasha Fogaça is now a professor at the Faculty of Economics, Administration, Accounting and Public Policy Management (Face) of UnB; Francisco A. Coelho Junior is now a professor at Face of UnB; Tatiane Paschoal is now a professor at Face of UnB; Mario C. Ferreira is now a professor at PSTO of UnB; Camila C. Torres is now a professor at the Department of Psychology of Iesb University Center.

Correspondence concerning this article should be addressed to Natasha Fogaça, campus universitário Darcy Ribeiro, Asa Norte, Brasília, Distrito Federal, Brazil, CEP 70910-900.

E-mail: natasha.adm@gmail.com

\section{EDITORIAL BOARD}

Editor-in-chief

Gilberto Perez

Associate editor

Gardênia da Silva Abbad

Technical support

Vitória Batista Santos Silva

\section{EDITORIAL PRODUCTION}

Publishing coordination

Jéssica Dametta

Language editor

Daniel de Almeida Leão

Layout designer

Emap

Graphic designer

Libro 